\title{
ASURANSI JIWA SYARIAH: Konsep dan Sistem Operasionalnya
}

Hadi Daeng Mapuna

Fakultas Syariah dan Hukum UIN Alauddin Makassar

\section{Abstract}

Islamic Insurance or better known as Sharia Insurance is one of the non-bank financial instruments that is used as a medium for the public in anticipating risks that might occur in the future. Sharia insurance is an alternative for the community, especially the Muslim community, which forbids conventional insurance. But in its development, Islamic insurance is still not developing as fast as conventional insurance. How the concepts and operational systems of Sharia Insurance will be discussed in this paper.

Keywords: Insurance, Conventional Insurance, Sharia Insurance

\section{A. PENDAHULUAN}

Islamic Insurance (Asuransi Islam) atau yang lebih dikenal dengan Asuransi Syariah (Syariah Insurance) adalah salah satu instrumen keuangan non bank yang dijadikan sebagai media bagi masyarakat dalam mengantisipasi resiko-resiko yang mungkin akan terjadi di masa yang akan datang. Asuransi Syariah merupakan alternatif bagi masyarakat, khususnya masyarakat muslim, yang mengharamkan asuransi konvensional.

Asuransi Syariah di Indonesia, sejak mulai dikembangkan tahun 1994, belum mengalami perkembangan yang signifikan. Pertumbuhan asuransi syariah dari waktu ke waktu belum mampu mengejar apalagi menyamai asuransi konvensional. Pada hal kehadiran asuransi syariah cukup mendapat respon positif dari masyarakat, bukan hanya oleh masyarakat muslim, tetapi juga oleh non muslim. Dengan demikian, sejatinya asuransi syariah di Indonesia mengalami pertumbuhan yang pesat.

Jika dibandingkan dengan asuransi konvensional, asuransi syariah masih tertinggal jauh. Menurut rilis Otoritas Jasa Keuangan (OJK) pada tahun 2017, aset asuransi syariah hanya Rp. 34,3 Trilyun, sementara aset asuransi konvensional mencapai 958,06 Trilyun. Market share (pangsa pasar) asuransi syariah masih rendah, yaitu hanya 3,45 \% dari seluruh asuransi. ${ }^{1}$

Asuransi syariah terdiri atas asuransi jiwa dan asuransi umum. Perbedaan antara keduanya terletak pada obyek pertanggungan. Asuransi jiwa syariah, pertanggungannya adalah manusia sedangkan asuransi umum syariah, obyek pertanggungannya adalah harta benda, misalnya; rumah, mobil, kapal, dan harta benda lainnya. Selain perbedaan obyeknya, mekanisme kerja asuransi jiwa syariah dan asuransi umum syariah juga berbeda. Meskipun demikian,

\footnotetext{
${ }^{1}$ https:// finansial.bisnis.com/ read/ 20190108/ 215/ 876547/ penetrasi-industri-asuransi-syariahstagnan, Kamis, 8 Agustus 2019.
} 
kedua jenis asuransi syariah tersebut memiliki prinsip yang sama, yaitu tolong menolong (ta'awun). ${ }^{2}$

Prinsip tolong menolong yang menjadi tujuan utama asuransi jiwa syariah merupakan implementasi dari Firman Allah swt., dalam Al Qur'an surat al Maidah ayat 2: "Dan tolong menolonglah kamu dalam (mengerjakan) kebaikan dan takwa, dan jangan tolong menolong dalam berbuat dosa dan pelanggaran."

Peserta asuransi jiwa syariah saling tolong menolong dan melindungi melalui kontribusi ke Dana Tabarru. Dana tabarru yaitu kumpulan dana kebajikan dari uang kontribusi para peserta Asuransi Jiwa Syariah yang setuju untuk saling bantu apabila terjadi risiko di antara mereka. Dana ini kemudian dikelola sesuai prinsip Syariah dan di bawah pengawasan Dewan Pengawas Syariah (DPS) ${ }^{3}$ untuk menghadapi risiko tertentu.

Apabila terjadi risiko terhadap peserta, santunan asuransi akan dibayarkan dari Dana Tabarru. Konsep ini juga dikenal sebagai risk sharing. Sementara, dalam Asuransi Jiwa Konvesional, Nasabah membayarkan sejumlah premi atas proteksi yang dibelinya ke perusahaan asuransi. Apabila terjadi risiko atas nasabah, perusahaan asuransi jiwa akan memberikan sejumlah santunan asuransi. Konsep ini juga dikenal sebagai risk transferring.

Ada beberapa perbedaan mendasar antara Asuransi Jiwa Syariah dan Asuransi Jiwa Konvesional dari segi kontrak, kepemilikan dana, surplus underwriting, pengelolaan investasi dan pengawasan asuransi. Dalam Asuransi Jiwa Syariah, ada beberapa jenis transaksi yang harus dihindari yaitu gharar atau ketidakpastian, riba atau tambahan dan maysir atau judi. Jadi, dana Nasabah pada Asuransi Jiwa Syariah khususnya unit link, tidak akan diinvestasikan pada hal-hal yang bertentangan dengan syariat Islam, contohnya produk keuangan dan perbankan dengan konsep riba, rokok, dan minuman keras.

Asuransi jiwa Syariah sebetulnya sangat baik, terutama dalam rangka menyiapkan sejumlah dana yang akan diberikan kepada ahli waris jika terjadi resiko kematian. Apalagi jika hal itu terjadi pada seorang tulang punggung keluarga. Dapat dibayangkan bagaimana keberlanjutan kehidupan orang-orang yang ditinggalkan. Dapat dipastikan bahwa mereka akan menghadapi kesulitan-kesulitan ekonomi atau setidak-tidaknya mereka harus bekerja keras untuk mendapatkan biaya hidup sehari-hari. Lain halnya jika seseorang memiliki asuransi jiwa syariah, setidak-tidaknya dapat membantu keluarga yang ditinggalkan, warisan berupa uang pertanggungan dapat dijadikan sebagai biaya pendidikan atau dijadikan sebagai modal usaha.

\footnotetext{
${ }^{2}$ Muhammad Syakir Sula, Asuransi Syariah; Life and General (Jakarta: Gema Insani Press, 2004),
} h. 229

3 Dewan Pengawas Syariah adalah orang-orang yang diangkat oleh Rapat Umum Pemegang Saham atas rekomendasi Dewan Syariah Nasional (DSN) - sebuah badan di bawah Majelis Ulama Indonesia (MUI) -- yang bertugas memberikan nasihat dan saran kepada direksi serta mengawasi kegiatan Lembaga Keuangan Syariah (LKS) agar sesuai dengan prinsip syariah. Dikutip dari : Beritagar.id, Jumat, 9 Agustus 2019. 
Namun demikian, pada umumnya masyarakat Indonesia belum menyadari pentingnya memiliki perencanaan keuangan berupa asuransi. Mereka lebih memilih investasi-investasi yang berwujud benda, misalnya; tanah, emas, dan property. Asuransi belum menjadi pilihan atau prioritas dalam mempersiapkan warisan.

Terlepas dari masih rendahnya kesadaran masyarakat untuk memiliki program asuransi jiwa syariah, dalam tulisan ini akan dikemukakan konsep dan sistem operasional asuransi jiwa syariah. Ini penting dikemukakan karena hal ini menjadi titik awal dalam meningkatkan pemahaman masyarakat terhadap asuransi jiwa syariah. Tulisan ini diharapkan dapat memberi pemahaman yang utuh mengenai asuransi jiwa syariah, termasuk memahami perbedaan-perbedaannya dengan asuransi konvensional.

\section{B. PENGERTIAN DAN ASAL USUL ASURANSI SYARIAH}

Sebelum mengemukakan pengertian asuransi jiwa syariah, terlebih dahulu penulis kemukakan pengertian asuransi secara umum. Kata asuransi berasal dari bahasa Belanda, assurantie, yang dalam hukum Belanda disebut Verzekering yang berarti pertanggungan. Dari istilah assurantie kemudian lahir istilah assuradeur bagi penanggung dan greassureerde bagi tertanggung. ${ }^{4}$ Dalam bahasa Inggris, asuransi diistilahkan dengan insurance; penanggung diistilahkan dengan insurer dan tertanggung diistilahkan dengan insured. ${ }^{5}$

Mark R. Greene, sebagaimana dikutip Muhammad Syakir Sula dalam bukunya Asuransi Syariah; Life and General, mendefinisikan asuransi sebagai an economic institution that reduces risk by combining under one management and group of objects so situated that the aggregate accidental losses to which the group is subject become predictable within narrow limits (Institusi ekonomi yang mengurangi resiko dengan menggabungkan di bawah satu manajemen dan kelompok obyek dalam suatu kondisi sehingga kerugian besar yang terjadi yang diderita oleh suatu kelompok tersebut dapat diprediksi dalam lingkup yang lebih kecil). ${ }^{6}$

Di Indonesia, pengertian asuransi secara baku telah disebutkan dalam UU No. 2 Tahun 1992 tentang Usaha Perasuransian. Di dalam UU tersebut dinyatakan bahwa asuransi atau pertanggungan adalah perjanjian antara dua pihak atau lebih. Satu pihak disebut sebagai penanggung dan pihak lainnya disebut sebagai tertanggung. Pihak penanggung mengikatkan diri kepada tertanggung dengan menerima sejumlah premi asuransi, untuk memberikan penggantian kepada tertanggung karena kerugian, kerusakan, atau kehilangan keuntungan yang diharapkan. Atau tanggung jawab hokum kepada pihak ketiga yang mungkin akan diderita tertanggung, yang timbul dari suatu

${ }^{4} \mathrm{KH}$ Ali Yafie, Asuransi dalam Pandangan Syariat Islam, Menggagas Fiqih Sosial (Bandung : Mizan, 1994), h. 205-206

${ }^{5}$ Bambang Trim (ed.), Solusi Berasuransi; Lebih Indah dengan Syariah (Bandung: Salamadani, 2009), h. 3.

${ }^{6}$ Muhammad Syakir Sula, Asuransi Syariah; h. 26. 
peristiwa yang tidak pasti; atau untuk memberikan suatu pembayaran yang didasrkan atas meninggal atau hidupnya seseorang yang dipertanggungkan. ${ }^{7}$

Dari definisi di atas dapat dipahami bahwa asuransi adalah sebuah kontrak atau perjanjian antara dua pihak atau lebih dalam rangka mengantisipasi resiko-resiko yang mungkin akan terjadi di masa-masa yang akan datang namun tidak diketahui waktunya yang pasti. Pihak-pihak yang melakukan kontrak dalam asuransi disebut sebagai penanggung dan tertanggung.

Obyek yang dipertanggungkan, sebagaimana disebut dalam UU No. 2 Tahun 1992 di atas, adalah resiko-resiko kerugian terhadap asset-aset, usaha, maupun jiwa manusia. Pengertian tersebut mencakup apa yang disebut sebagai asuransi umum dan asuransi jiwa. Asuransi dalam pengertian di atas dikategorikan sebagai asuransi konvensional.

Selain asuransi konvensional, ada juga yang dikategorikan sebagai Asuransi Syariah. Asuransi Syariah $\left(\mathrm{Ta}^{\prime} \mathrm{min}^{8}\right.$, Takaful ${ }^{9}$, Tadhamun $\left.{ }^{10}\right)$ adalah usaha saling melindungi dan tolong menolong di antara sejumlah orang/pihakmelalui investasi dalam bentuk asset dan atau tabarru' yang memberikan pola pengembalian untuk menghadapi risiko tertentu melalui akad (perikatan) yang sesuai dengan syariah. ${ }^{11}$

Berdasarkan definisi tersebut dapat dipahami bahwa inti dari asuransi syariah adalah saling melindungi dan tolong menolong (ta'awun). Dengan demikian dapat dikatakan bahwa asuransi syariah sangat relevan dengan ajaran atau nilai-nilai kehidupan bersama (bermasyarakat) yakni kebersamaan. Anggota masyarakat yang satu senantiasa membantu anggota masyarakat lainnya. Hal ini menjadi semakin penting jika dikaitkan dengan ukhuwah Islamiyah (persaudaraan sesama muslim).

Dalam Asuransi Syariah, antara penanggung dan tertanggung tidak terpisah. Peserta menjadi penanggung sekaligus menjadi pihak yang ditanggung atau tertanggung. Sebab prinsipnya tolong menolong. Perusahaan asuransi hanya berperan sebagai operator yang menerima amanah dari peserta untuk mengelola kontribusi yang disetorkan oleh nasabah. Hal ini berbeda

7 Dewan Asuransi Indonesia, Undang-Undang Republik Indonesia No. 2 Tahun 1992 dan Peraturan Pelaksanaan Tentang Usaha Perasuransian, Edisi 2003, DAI, h. 2-3.

${ }^{8}$ Asuransi dalam bahasa Arab disebut Ta'min atau Att'min berasal dari kata aaman yang memiliki arti memberi perlindungan, rasa aman dan bebas dari rasa takut. Dikutip dari m. republika.co.id, Jumat, 8 Agustus 2019.

${ }^{9}$ Takaful (Bahasa Arab : Attakaaful) adalah konsep Asuransi Syariah. Takaful adalah solidaritas, mencukupi kebutuhan hidup dan mengasuh, seperti kondisi kekurangan yang timbul pada salah satu pihak yang mendesak hubungan saling mencukupi. Takaful adalah interaksi antara dua pihak atau lebih. tps://id.m.wikipedia.org.

${ }^{10}$ Tadhamun adalah usaha saling melindungi dan tolong menolong diantara sejumlah orang/pihak melalui investasi dalam bentuk asset dan/atau tabarru' yang memberikan pola pengembalian untuk menghadapi resiko tertentu melalui akad (perikatan) yang sesuai dengan syariah. (https://www.takafulumum.co.id)

${ }^{11}$ Fatwa Dewan Syariah Nasional No. 21/DSN-MUI/X/2001 Tentang Pedoman Umum Asuransi Syariah. 
dengan Asuransi Konvensional yang menggunakan prinsip jual beli. Perusahaan asuransi sebagai penanggung dan peserta sebagai tertanggung.

Asal usul Asuransi Syariah adalah berasal dari budaya suku Arab pada zaman nabi Muhammad saw., yang disebut aqilah. ${ }^{12}$

Dalam Dictionary of Islam yang disusun oleh Thomas Patrick, sebagaimana dikuttip Bambang Trim, dijelaskan bahwa jika salah satu anggota suku terbunuh oleh suku lain, keluarga korban akan dibayar sejumlah uang darah (diyat) sebagai konpensasi oleh saudara terdekat dari pembunuh. Saudara terdekat pembunuh tersebut biasa disebut aqilah sebagai pembayar uang darah atas nama pembunuh. ${ }^{13}$

Lebih jauh dijelaskan bahwa Al-Aqilah mengandung pengertian saling memikul dan bertanggung jawab bagi keluarga. Dalam kasus terbunuhnya seorang anggota keluarga, ahli waris korban akan mendapatkan uang darah yang dibayarkan oleh anggota keluarga terdekat dari si pembunuh. Dana yang dipergunakan untuk membayar diyat tersebut dikumpulkan secara gotong royong oleh anggota keluarga yang terlibat dalam pembunuhan tersebut.

Dari uraian-uraian di atas dapat disimpulkan bahwa asal mula Asuransi Syariah adalah perlindungan terhadap jiwa seseorang, yang saat ini disebut sebagai Asuransi Jiwa Syariah. Lain halnya dengan Asuransi Konvensional yang lahir di Eropa Barat pada abad pertengahan. Pada mulanya asuransi dimaksudkan untuk melindungi harta benda, yaitu asuransi kebakaran. Selanjutnya, pada abad ke-13 dan ke-14 lahir asuransi pengangkutan laut. ${ }^{14}$ Asuransi jiwa konvensional mulai dikenal pada abad ke-19.

Konsep dasar asuransi syariah adalah antara penanggung dan tertanggung tidak terpisah. Peserta adalah tertanggung sekaligus sebagai penanggung. Sebagai tertanggung, peserta atau ahli warisnya akan memperoleh pembayaran atas kerugian nilai ekonomis yang dialami sebagai akibat terkena resiko sakit, cacat akibat kecelakaan atau meninggal dunia.

Dana pembayaran tersebut diambil dari dana kumpulan seluruh peserta yang disebut sebagai Dana Tabarru'. Masing-masing peserta berkontribusi (dalam asuransi konvensional disebut premi) sesuai ketentuan yang diatur di dalam perusahaan asuransi. Dalam kondisi ini, peserta berfungsi sebagai penanggung. Sebab, dana merekalah yang dipergunakan untuk membayar klaim jika ada peserta yang terkena resiko.

Jika demikian, bagaimana posisi perusahaan asuransi syariah? Perusahaan asuransi syariah hanya berperan sebagai operator (pengelola) yang bertugas mengurus administrasi data kepesertaan, mengelola risiko, mengelola dana tabarru' dan membayarkan klaim sesuai dengan yang diperjanjikan. Sebagai imbalan atas pekerjaan tersebut, perusahaan asuransi memperoleh fee (upah) dan atau bagi hasil dari pengelolaan dana yang terkumpul dari peserta.

\footnotetext{
12 Bambang Trim (ed.), Solusi Berasuransi; 2009, h. 3.

${ }^{13}$ Bambang Trim (ed.), Solusi Berasuransi, 2009, h. 4.

${ }^{14}$ Bambang Trim (ed.), Solusi Berasuransi, 2009, h. 3.
} 


\section{SISTEM OPERASIONAL ASURANSI (JIWA) SYARIAH}

Seperti telah dijelaskan pada bagian terdahulu bahwa antara prinsip dasar asuransi syariah adalah ta'awun atau tolong menolong. Konsep mengenai tertanggung dan penanggung yang terpisah, sebagaimana dalam asuransi konvensional, tidak berlaku dalam asuransi syariah.

Bertolak dari prinsip ta'awun dan saling menanggung tersebut maka sistem operasional asuransi jiwa syariah tentu berbeda dengan system operasional asuransi jiwa konvensional. Sistem operasional asuransi jiwa syariah senantiasa menghindari adanya unsur gharar ${ }^{15}$, maisir ${ }^{16}$, dan riba.

Untuk menghindari adanya unsur gharar, maysir dan riba, maka dalam asuransi jiwa syariah menggunakan dua akad, yaitu akad tabarru atau biasa juga disebut akad takafuli dan akad mudharabah (bagi hasil). Dalam operasionalnya, asuransi syariah menyiapkan rekening khusus sebagai rekening dana tolong menolong atau rekening tabarru' yang menampung kontribusi yang disetorkan oleh seluruh peserta yang telah diniatkan untuk membantu sesama peserta. ${ }^{17}$

Setiap peserta menyetorkan kontribusi kepada pengelola (perusahaan) dan selanjutnya pengelola akan mengalokasikan ke dalam dua rekening, yakni rekening tabarru' atau derma (rekening bersama) dan rekening pribadi peserta. Jika seorang peserta terkena resiko sakit, kecelakaan atau meninggal, maka klaimnya akan dibayarkan atau diambilkan dari rekening tabarru'. Melalui mekanisme ini, tampak dengan jelas setiap peserta berkontribusi atau berderma kepada peserta yang terkena resiko tersebut.

Penjelasan lebih gamblang berkaitan dengan hal ini diberikan oleh Syafi'i. Antonio. Menurut Syafi'i Antonio, masalah gharar dalam asuransi jiwa syariah dapat dieliminir karena akad yang dipakai adalah akad takafuli atau akad tolong-menolong dan saling menjamin. "Dalam konsep asuransi syariah, semua peserta asuransi menjadi penolong dan penjamin satu sama lainnya. Jika peserta (A) meninggal, peserta (B), (C), hingga (Z) turut membantunya. Demikian pula sebaliknya". ${ }^{18}$

Sebagai ilustrasi, seorang peserta asuransi membayar kontribusi Rp. 1 juta /bulan untuk jangka waktu 10 tahun. Setelah dihitung oleh pihak under writing, $^{19}$ maka peserta tersebut ditetapkan akan mendapatkan Uang Pertanggungan sebesar Rp. 150 juta jika meninggal dunia. Namun, peserta

${ }^{15}$ Gharar atau taghrir adalah istilah dalam kajian hukum Islam yang berarti keraguan, tipuan, atau tindakan yang bertujuan untuk merugikan orang lain. Al-gharar adalah al-mukhatarah (pertaruhan) dan aljahalah (ketidakjelasan) sehingga termasuk dalam perjudian. Lihat, https://id.m.wikipedia.org/gharar.

${ }^{16}$ Maysir - Maisir (perjudian) artinya bertaruh, baik dengan uang atau benda. Kata Maisir dalam bahasa Arab secara harfiah berarti memperoleh sesuatu dengan sangat mudah tanpa kerja keras atau mendapat keuntungan tanpa bekerja. Lihat, https://id.m.wikipedia.org/maysir.

${ }^{17}$ Muhammad Syakir Sula, Asuransi Syariah; h. 174-175.

18 Muhammad Syafi'I Antonio, Asuransi Dalam Perspektif Islam (Jakarta: Syarikat Takaful Indonesia, 1994), h. 2.

19 Underwriting adalah bagian dalam asuransi jiwa syariah yang bertugas menghitung besarnya kontribusi yang harus dibayar oleh peserta dan besarnya Uang Pertanggungan yang diperoleh oleh peserta jika meninggal dunia. Dalam menentukan besarnya kontribusi dan uang pertanggungan, underwriting menggunakan data mengenai usia, pekerjaan dan status merokok peserta. 
tersebut meninggal saat kepesertaannya baru berjalan 4 tahun. Dengan demikian, peserta tersebut baru menyetorkan dana sebesar Rp. 48 jt. Saat dia meninggal, ahli warisnya akan memperoleh santunan sebesar Rp. 150 juta. Pertanyaannya, dari mana dana Rp. 150 juta yang diberikan kepada ahli warisnya sedangkan dananya yang masuk baru Rp. 48 juta?

Jawabannya adalah, dana Rp. 150 juta tersebut diambil dari kas dana tabarru' atau dana yang terkumpul dari peserta seluruhnya. Bukankah peserta dalam hal ini ahli warisnya beruntung dan perusahaan merugi? Tentu tidak demikian, karena dana tabarru' merupakan hibah atau derma dari seluruh peserta yang memang diniatkan untuk membantu jika ada diantara peserta yang mengalami resiko sakit, kecelakaan atau meninggal. Dana tersebut bukan milik perusahaan melainkan milik bersama peserta. Perusahaan asuransi hanya menerima amanah untuk mengelolah dana tersebut.

Dengan demikian dalam asuransi syariah tidak ada yang untung dan tidak ada yang rugi. Yang ada adalah saling tolong menolong satu sama lainnya melalui mekanisme pengumpulan dana tabarru' sebagai dana kebajikan. Asuransi syariah menjadi salah satu jalan bagi seseorang untuk membantu sesamanya jika terkena resiko kehidupan.

\section{KESIMPULAN}

Dari uraian-uraian di atas dapat diambil kesimpulan bahwa Asuransi syariah merupakan sebuah kontrak kerjasama antara seorang peserta dengan peserta lainnya untuk saling membantu dalam mengantisipasi resiko-resiko kehidupan yang akan terjadi di masa depan. Setiap peserta menjadi penanggung sekaligus tertanggung bagi peserta lainnya.

Asal usul asuransi syariah adalah berasal dari tradisi masyarakat Arab pada masa Nabi Muhammad saw., yang disebut aqilah. Jika ada seseorang yang meninggal (dibunuh) oleh seseorang, maka keluarga dekat pembunuh wajib membayar uang darah (diyat) kepada ahli waris korban. Uang darah tersebut dikumpulkan dari para keluarga pembunuh lalu diserahkan kepada ahli waris korban. Tradisi inilah yang kemudian berkembang menjadi asuransi syariah yang dikenal saat ini.

Sistem operasional asuransi syariah adalah menggunakan dua akad, yaitu akad tabarru' dan akad mudharabah. Dengan adanya dua akad ini maka unsur gharar, maysir dan riba dapat dihilangkan.

Perusahaan asuransi jiwa syariah membuat dua rekening untuk menampung dan mengembangkan dana kontribusi peserta. Satu rekening untuk menampung dana hibah atau derma yang disebut sebagai rekening tabarru' dan satu rekening lagi untuk menampung dana peserta sebagai dana investasi. Jika ada peserta yang mengalami resiko sakit, kecelakaan, atau meninggal, maka perusahaan asuransi jiwa syariah akan membayarkan santunan kepada ahli waris yang diambil dari rekening tabarru'. 


\section{DAFTAR PUSTAKA}

Amrin, Abdullah. Strategi Menjual Asuransi Syariah. Jakarta: PT. Elex Media Komputindo, 2012.

Antonio, Muhammad Syafi'i. Asuransi Dalam Perspektif Islam. Jakarta: Syarikat Takaful Indonesia, 1994.

Dewan Asuransi Indonesia (DAI). Undang-Undang Republik Indonesia No. 2 Tahun 1992 dan Peraturan Pelaksanaan Tentang Usaha Perasuransian, Edisi 2003,

Fatwa Dewan Syariah Nasional No. 21/DSN-MUI/X/2001 Tentang Pedoman Umum Asuransi Syariah.

Sula, Muhammad Syakir. Asuransi Syariah; Life and General. Jakarta: Gema Insani Press, 2004.

Trim, Bambang (ed.). Solusi Berasuransi; Lebih Indah dengan Syariah. Bandung: Salamadani, 2009.

Yafie, KH Ali. Asuransi dalam Pandangan Syariat Islam, Menggagas Fiqih Sosial. Bandung : Mizan, 1994.

\section{Media Online}

Beritagar.id

https:// finansial.bisnis.com/ read/ 20190108/ 215/ 876547/ penetrasiindustri-asuransi-syariah-stagnan

https://id.m.wikipedia.org/gharar.

https://id.m.wikipedia.org/maysir.

https://www.takafulumum.co.id

m.republika.co.id

tps://id.m.wikipedia.org./takaful. 